\title{
Weak Form of Efficient Market Hypothesis - Evidence from Pakistan
}

\begin{abstract}
Naimat U. Khan ${ }^{1}$, Sajjad Khan ${ }^{2}$
Abstract

This research is an empirical investigation of the weak form of efficiency of the Karachi Stock Exchange (KSE-100) Index, which is the prominent index of Pakistan Stock Exchange (formerly Karachi Stock Exchange). The contribution of this paper is to analyze a longer 24 years' sample period (1991-2015) with three frequencies of data-daily, weekly and monthly index returns. The results show that return series of three frequencies have a negatively skewed, leptokurtic and non-normal distribution. The non-parametric Phillips-Perron (PP) test and parametric Augmented Dickey-Fuller (ADF) test rejected the non-stationarity hypothesis for index returns at the level for all daily, weekly and monthly data. The auto-correlation of randomness for the chosen period rejected the Random Walk Hypothesis (RWH) for daily and weekly index returns but documented the existence of $R W H$ for monthly index returns. Lastly, the findings of run tests show market inefficiency on daily and weekly data and efficiency for monthly returns. The findings are not consistent with efficiency theory as the stock returns do not follow the random walk hypothesis and hence nullify weak form of efficiency for daily and weekly returns. However, the research documents weak-form of efficiency for monthly returns; the existence of randomness in monthly data is not surprising for an emerging market like Pakistan which does not have a long memory to remember previous monthly prices. Positioned upon weak form of efficiency assumption, the investors on the KSE can make abnormal returns on the basis of historical share prices (Malhotra, Tandon, $\mathcal{E}$ Tandon, 2015). The concept of market efficiency is important for analysts, for investor's investment decisions, and regulators of stock exchange to improve the flow of information. Further research can be done with more sophisticated techniques of testing weak form of efficiency.
\end{abstract}

Keywords: Weak form, efficient market hypothesis, random walk hypothesis, Pakistan.

\section{Introduction}

Fama (1970), an American economist, who says that everything that can be known about a share has already been incorporated into the price of that share. Fama (1970) used the term 'efficient market' according to which "on the average, competition will

1 Assistant Professor, Institute of Management Studies, University of Peshawar. Email: naimatims@ yahoo.com

2 Lecturer, Northern University, Nowshera, Pakistan. 
cause the full effects of new information on intrinsic values to be reflected "instantaneously" in actual prices" (Fama, 1970). The EMH has three forms: weak, semi-strong and strong form of efficiency.

Weak form of Efficient Market Hypothesis (WF-EMH) states that the current prices of stocks fully incorporate all available information of previous share prices (Fama, 1970). Semi-Strong Form of Efficient Market Hypothesis (SSF-EMH) is one in which the present prices of shares reflect all available publically information along with past prices of shares (Fama, 1970). In Strong Form Efficient Market Hypothesis (SF-EMH), all available information (both public and private) is reflected in the stock prices (Fama, 1970).

The efficient market hypothesis is considered as an essential tool for investment purposes. Emerging economies attracts large investors for its high volatility and high returns (Akhtar \& Khan, 2016). Investors use the application of trading strategies for investment decisions; hence measuring efficiency of market has significant use for investors. Consequently, it is worthy to examine efficiency of Pakistani equity market in order to provide a good tool for predicting share prices and investments decision.

Research efforts were carried out on equity markets for the validity of the theory in the developed and emerging economies. For example, studies show that EMH is applicable in the US stock market (Kim, Shamsuddin, \& Lim, 2011; Seiler \& Rom, 1997). While, another study by Mishra (2011) does not support random walk model for other developed markets (US, UK and Germany) and emerging economies (Brazil, India, South Korea, China, Russia). Economic researchers such as Mobarek (2000) and Hasan, Kamil, Mustafa, and Baten (2012) rejected weak form of efficiency for Dhaka stock exchange and Abeyratna and Power (1995) rejected for Colombo Stock Exchange.

Similarly, literature about Pakistani market exists about weak form of efficiency; however this paper analyses a longer period of 24 years (1991-2015) data since the inception of KSE-100 index on November 2, 1991. In addition, this research analyses the KSE-100 index for three frequencies of data, i.e. daily, weekly and monthly, as compared to using only daily data by Rehman and Qamar (2014), and weekly data by Haque, Liu, and Nisa (2011). For testing weak form of efficiency, various econometric tools are employed such as Unit Root Tests, Autocorrelations, and Runs Test. It is important to mention that KSE-100 index is the prominent index to measure the performance of Karachi Stock Exchange (now Pakistan Stock Exchange, PSX; hereinafter PSX and KSE will be used interchangeably).

The research is not only an addition to the literature about emerging market 
but also helpful to the investors who design their investment strategies according to available information. The next section provides a literature review in both developed and emerging markets. Third section is about research methodology in which data, sources and research tools are discussed in detail. Fourth section covers detailed results. The last section outlines the findings and future direction for further studies.

\section{Literature Review}

The theoretical foundation of EMH traced back from random walk which was firstly put forwarded by Bachelier in his Ph.D dissertation back in 1900 (MacKenzie, 2006). He concluded that commodity prices fluctuate randomly (Jethwani \& Achuthan, 2013). The research by Working (1934) on the US Stock prices supported the random walk. The term "efficient market" was used for the first time by Fama (1965) which stated that stock market prices follow random walk. EMH is widely discussed area in finance literature with diverse results from both developed and emerging markets.

There are researches that documented the presence of WF-EMH for developed economies. The work done on the US equity market was supported by Kim et al. (2011), who analyzed daily index data of DJIA (Dow Jones Industrial Average Index) over the period January 1900-June 2009. The outcomes demonstrated that returns on the stock varied with time due to changes in market conditions and economic fundamentals. Similarly, Seiler and Rom (1997) supported the efficiency on the New York Stock Exchange, who studied the behavior of stock prices of all listed firms for the period (1885-1962) in order to predict the stock market. They observed random walk behavior in daily stock prices, however they found that performance of weekly and monthly returns were significant but still investors were unable to forecast the future trend. Sheikh and Noreen (2012) supported the WF-EMH for the UK equity market. They documented that the UK' Funds Managers were unable to predict the future stock behavior. Their findings were based on month to month returns data of 50 UK mutual funds over the time (1990-2008). The paper that supports the inefficiency in weak form for three developed and five emerging economies ${ }^{3}$ is by Mishra (2011) who studied the application of RWH in these economies. It was observed that these economies did not follow weak form of efficiency. However these inefficiencies were linked with the innovations, financial products and found that the markets turned to be efficient in long-run. Through co-integration analysis it was found that these markets were unable to follow EMH (Azad, 2009). The market inefficiency was evidenced by Opong, Mulholland, Fox, and Farahmand (1999) for London Financial Times Stock Exchange for the period (1986-1997) for all listed shares, and documented that the

3 China, India, Brazil, Russia, South Korea, Germany, UK and US, in the period from January 2007 to December 2010. 
changes in the stock prices are not independently and identically distributed. Laopodis (2004) supported the WF-EMH for Athens Stock Exchange for the period (1985 to 2001). They linked stock market behavior with the announcements of financial liberalization. Similarly, EMH validity is also proved in Istanbul Stock Market (ISE) by Aga and Kocaman (2008).

Weak form of efficiency was researched in emerging economies. Su, Roca, and Wong (2015) examine 16 markets consisting of 5 developed, 9 emerging and 2 frontier ones. The authors documented that all the developed markets were efficient while the frontier ones were all inefficient and mixed results for the less developed ones. In addition, they found that the level of efficiency of these markets varies over time where it decreased during the Global Financial Crisis and then increasing afterwards. Similarly, Malhotra et al. (2015) analyzed weak form of efficiency for 10 selected stock exchanges in Asia-Pacific markets for daily, weekly and monthly returns from 1997 to 2012 using run test and autocorrelation. The results showed that there existed weak form of efficiency for monthly returns but fail to exhibit characteristics of random walk in daily and weekly returns. The results have important implications for investors who can exploit market inefficiency and earn abnormal profits while holding a well-diversified portfolio in these emerging markets (Malhotra et al., 2015). Said and Harper (2015) studied weak form at Russian stock market over the period for daily index returns over the period from 2003 to 2012 using autocorrelation and Box-Ljung test statistics. The results showed that the market is not efficient in weak form. Pele and Voineagu (2008) documented EMH for Romanian Capital Market which is based on their own model of decomposition for stock returns. Mollah (2007) showed informational inefficiency for daily stock returns of Botswana Stock Exchange for a sample period from 1989 to 2005 using the triangulation econometric approach. Similarly, Ekechi (1989) found no evidence of RWH for Nigerian Stock Market over the period (1980-1986). The author documented that this result was consistent with Granger's (1975) that "it also seems likely that infrequently traded shares may not obey a random walk" (p. 479). Bley (2011) did not find weak form of efficiency for daily share prices of Gulf Stock market for 10 years (2000-2009). Similarly, Groenewold, Tang, and Yanrui (2004) documented the inefficiency of the China Stock Market. Chong, Lam, and Yan (2012) documented market efficiency Post-SOE reform in China. Their results evidenced that abnormal returns and abnormal profits occur in the pre-SOE reform period. They examined the Shanghai Composite Index (SHC Index) and the Shenzhen Composite Index (SZC Index) from 1991-2010. ${ }^{4}$

A significant work has been done in emerging markets of South Asia who reject-

4 The data is divided into four sub-sample periods i.e., the pre- SOE; the post-SOE; reform periods earlier to the latest financial crisis; the crisis and after crisis period. 
ed the WF-EMH. For example, Mobarek (2000) rejected the Dhaka Stock Exchange sample for EMH. For the same stock market, Hasan et al. (2012) also nullified the existence of weak form of efficiency for daily, weekly and yearly data over a period from 2000-2008. Similarly, Abeyratna and Power (1995) did not find weak form of efficiency at Colombo Stock Exchange for a sample of 20 companies for a sample period from 1990 to 2001. The Jung-Box tests were applied on daily, weekly and monthly data and result showed that behavior of stock prices were predictable from past information. Poshakwale (2002) statistical effects confirm that Indian stock market did not take after RWH using daily returns. In line with the previous studies, weak form of inefficiency was found for Indian market by Mukhopadhyay and Sarkar (2005) and Ahmad, Ashraf, and Ahmed (2006).

A number of researchers have conducted studies in Pakistani Equity market for testing weak form of efficiency. For example, Mustafa and Nishat (2007) observed weak form of efficiency for the daily, weekly and monthly data. Thin trading and non-linearity was considered for weekly and monthly data and the efficiency was found. Haider and Nishat (2009) contradicted the previous findings of efficiency and documented inefficiency for the KSE. On the basis of technical analysis, WF-EMH was rejected by Tahir (2011) for 20 listed companies on the KSE over the period from 2000 to 2009. Similarly, Haque et al. (2011) rejected the WF-EMH for KSE-100 Index for a weekly data over the ten years (2000-2010). His findings evidenced that past data had trends and can be used for prediction of future returns. In same line of market predictability, Kiani (2006) rejected EMH while using non-Gaussian state space or unobservable component model on the KSE-100 Index. Sultan, Madah, and Khalid (2013) compare weak form of efficiency of Karachi and Kuwait stock exchanges over the period from 2005 to 2010. Using ADF and autocorrelation, the results show inefficient EMH for both markets. Rehman and Qamar (2014) found market inefficiency at the KSE-100 index for two years (2009 and 2010) daily data using runs test, ACF test and the ADF.

In the light of the above mentioned literature, it is evident that diverse results are documented by various studies. In order to have more comprehensive results, the study takes a longer sample of 24 years for daily, weekly and monthly data of KSE100 index. In addition, the study uses both parametric and non-parametric tests for measuring weak form of efficiency.

\section{Methodology}

The study seeks evidence that the KSE follows RWH and the market is efficient in weak form. The null hypothesis of the study is: Ho - The Karachi stock market is not efficient in weak form. And the alternative hypothesis is: H1 - The Karachi 
stock market is efficient in weak form. Firstly, daily, weekly and monthly returns were calculated from the closing the KSE-100 index. The returns were calculated as $R_{t}=$ $\ln \left(\mathrm{p}_{\mathrm{t}} / \mathrm{p}_{\mathrm{t}-1}\right)$, where $\mathrm{p}_{\mathrm{t}}$ is the current index price and $\mathrm{p}_{\mathrm{t}-1}$ is lagged index at time $\mathrm{t}-1$. The closing prices of all KSE-100 indexes were obtained from "Yahoo Finance" for 24 years from November 1991 to December 2015. The total daily observations are 5871; weekly observations are 1255 and monthly observations are 289. For this purpose, both parametric (Augmented Dickey-Fuller test of Unit Root and Autocorrelation Test) and non-parametric tests (Phillips-Perron of unit root test and Runs test) are used. These tests are more suitable for emerging markets and there is no need to test with the help of sophisticated (Sultan et al., 2013; Rehman \& Qamar, 2014; Su et al., 2015; Said \& Harper, 2015; Malhotra et al., 2015). There are some alternative models for testing random walk which has been proved more robust such as LOMAC single variance ratio, GPH fractional integration, ranked - and sign-based variance ratio proposed by Wright (2000). However, this study focuses on emerging market of Pakistan which is not sophisticated for using more robust tests. In addition, the results of this study justify our argument as overall results support inefficiency of market, therefore using more sophisticated models will be redundant and contradicts the basic element of parsimony in research.

\subsection{Unit Root Tests}

To examine the RWH unit root test is used which serves as eventual criteria for testing the WFH. The randomness in the return series makes certain that successive stock prices are independent and identically circulated. The random walk theory ensures that current prices $\left(\mathrm{p}_{\mathrm{t}}\right)$ are free and independent of past prices $\left[\left(\mathrm{p}_{\mathrm{t}-1}\right), \mathrm{p}_{\mathrm{t} 2}\right)$, $\left.\left(\mathrm{p}_{\mathrm{t}-3}\right) \ldots ..\right]$ and not supportive in the prediction of prospect prices $\left(\mathrm{p}_{\mathrm{t}+1}\right)$. The ADF unit root test is used in autoregressive series.

$$
\mathrm{P}_{\mathrm{t}}=\mu+\mathrm{rP}_{\mathrm{t}-1}+€_{\mathrm{t}}
$$

Whereas $P_{t}$ is the current value, $P_{t-1}$ is the lag value of the returns, the parameter $\mu$ is the mean and " $\Theta_{t}$ " is the random error term. From econometric perspective, a random walk series need a unit root during structural/form level and might turned into stationary at first or second difference. Haque et al. (2011) suggested that unit root in a series provides the source of random walk and as a result it lead to weak form of efficiency. Otherwise, rejection of unit root at the level data refers that successive shifts in share prices contain deterministic trend and dependent of each other. The research uses largely acceptable unit root tests, i.e. Augmented Dickey-Fuller (ADF) and Phillips-Perron. Unit root test is done by examining the coefficient $(\rho)$ value of $\mathrm{P}_{\mathrm{t}-1}$ is larger than 1 or equals to it. The null hypothesis of $\mathrm{H}_{0}:|\rho|>1$ means that the variance of series is irrepressible and prices variations are independent and cannot 
be predicted. The data has a unit root and it is non-stationary. Acceptance of $\mathrm{H}_{0}:|\rho|$ $>1$ means various price fluctuations are independent and that the variance of the data is uncontrollable and unpredictable, which eventually supports the RWH. The acceptance of random walk refers that the series move randomly and market is efficient in its weak form.

Another alternative non-parametric technique is P-P to measure unit root test in a series (Phillips \& Perron, 1988). In ADF test statistics, t-statistics is used for lagged values and in $p$-p test statistics, a modified or adjusted t-statistics is used, which ignore the serial correlation and heteroskedasticity in the error term $\mu$ of the test.

$$
\Delta \mathrm{y}_{\mathrm{t}}=\beta^{\wedge} \mathrm{D}_{\mathrm{t}}+\pi \mathrm{y}_{\mathrm{t}-1}+\mu_{\mathrm{t}} \mu \sim \mathrm{I}(0)
$$

Where $\Delta$ is the difference operator, $y$ is the variable of interest, $\square^{\wedge}$ is a constant, $\pi$ is the slope, $\mu$ is the error term and $t$ is the transcript for time. The non-parametric P-P test is used to find any heteroskedasticity and serial correlation in the errors $\mu_{t}, \mu_{t}=0$. The null hypothesis test along with trend stationarity correspond that random walk variance equal to zero. Afterward time series is considered stationary and changes in prices are independent of each other and unpredictable, hence supports the RWH.

\subsection{Autocorrelation Test}

Autocorrelation test with assumption that different values at lags are not correlated then they cannot be used for prediction and the series is considered as random or stochastic (Mobarek, 2000; Haque et al., 2011; Tahir, 2011; and Kiani, 2006). While classical liner regression assumes that autocorrelation does not lie in the disturbance $u_{i}$ : i.e.,

$$
E(u i u j) \quad i \neq j
$$

According to the assumptions of the model any one observation distribution terms is not influenced by any other observation disturbance term. The autocorrelations and Ljung Box Q-statistics are further provides the randomness of the return series. The auto-correlation test for randomness and serial correlation is employed on the return series for sample period. The Q-statistic assumes that under the null hypothesis $\left(\mathrm{H}_{0}\right)$, all autocorrelations equal to zero. It refers that when different figures are not correlated, it cannot predict the future returns and eventually it is random or stochastic series (Haque et al., 2011). In case the Q-statistic is significant, null hypothesis is rejected, which refers that successive figures are correlated to one another. Hence there is predictability in future values and eventually the returns are not random and the series is not efficient in weak form. Partial autocorrelation and autocorrelation shows that time series has serial correlation or no autocorrelation in specified sample period. 
Furthermore, run test is used in order to check randomness of returns.

\subsection{Runs Test}

Finance literature documented that non-parametric (i.e., Run test) can verify the randomness of the time series (Fama, 1965; Wong \& Kwong, 1984; Sharma \& Kennedy, 1977; Cooper, 1982; Chiat \& Finn, 1983; Yalawar, 1988; Butler \& Malaikah, 1992; Poshakwale, 1996; Mobarek, 2000; and Haque et al., 2011). In run test, a hypothesis of serial independence is tested to measure the independent of the consecutive occurrences of runs. A run is a series of consecutive negative returns (-) or positive $(+)$ and its length is account of successive signs. It does not require any specific probability distribution as it is a non-parametric test and both positive and negative runs are used as test statistics count. Under random walk assumptions, actual value of runs and the expected value of runs are equal.

$$
\mathrm{N}=\mathrm{N}_{+}+\mathrm{N}_{-}
$$

Where $(\mathrm{N})$ is the total amount of runs; $\left(\mathrm{N}_{+}\right)$is the amount of positive runs; $(\mathrm{N})$ amount of negative runs. Consecutive runs are independent of each other under null hypothesis $\mathrm{H}_{0}$. The null hypothesis of randomness is rejected if $\mathrm{Z}$-value is larger than or equal to $( \pm 1.96)$ at $95 \%$ level of significant.

\section{Results Analysis}

The results of the tests are as follows.

\subsection{Descriptive Statistics}

Table 1 shows the descriptive statistics for the returns series of daily (Panel A), weekly (Panel B) and monthly (Panel C) over the period from 1991 to 2015. In addition, Figure 1 and Figure 2 in the appendix section depict trends of closing index prices and index returns, respectively.

In our sample, the mean of return series is $0.000589,0.002703$ and 0.010841 with standard deviation of $0.015095,0.036074$ and 0.089584 for daily, weekly and monthly returns respectively. The returns have negative skewness for three frequencies of returns, it refers that there are more negative returns in the data set (Haque et al., 2011). Furthermore, the returns are leptokurtic as it has a positive kurtosis for daily, weekly and monthly data as the value is more than normal distribution of $3 .{ }^{5}$ The negative skewness and high value of leptokurtic for the return series demonstrates

5 Kendall (1943) documented that the expected normal kurtosis equal to 3. 
Table 1: Descriptive Statistics of KSE-100 Index Returns

\begin{tabular}{|c|c|c|c|}
\hline & \multicolumn{3}{|c|}{ Descriptive Statistics Sample $11 / 2 / 1991$ 12/31/2015 } \\
\hline & Daily Index Return & Weekly Index Return & Monthly Index Return \\
\hline Observations & 5871 & 1255 & 289 \\
\hline Mean & 0.000589 & 0.002703 & 0.010841 \\
\hline Median & 0.000840 & 0.004672 & 0.019439 \\
\hline Standard Deviation & 0.015095 & 0.036074 & 0.089584 \\
\hline Kurtosis & 8.719339 & 6.502717 & 6.749954 \\
\hline Skewness & -0.251622 & -0.672693 & -0.828537 \\
\hline Minimum & -0.132133 & -0.200976 & -0.448796 \\
\hline Maximum & 0.127622 & 0.142748 & 0.246047 \\
\hline J-B Statistics & 8063.841 & 736.2192 & 202.3969 \\
\hline p-value & $0.000000^{*}$ & $0.000000^{*}$ & $0.000000^{*}$ \\
\hline
\end{tabular}

Note: P-Values are for J-B statistics for checking normality of data with the null hypothesis of normality of returns.

that it is not a normal distribution for the test period (Haque et al., 2011). The non-normality of three set of data is further justified with the significant values of P-value for Jarque-Bera.

\subsection{Results of Unit Root Tests}

After descriptive statistics, the empirical analysis is documented for Unit root tests in Table 2 and 3. The results of ADF test for daily, weekly and monthly returns at level form are given in Panel A, Panel B and Panel C respectively in Table 2. The results show that daily, weekly and monthly series are stationary and having no unit root or trend in data as the respective P-value are less than 0.05 at $5 \%$ level of significance. It rejects the null hypothesis that the series has a level unit root; subsequently the data became stationary at level.

Similarly, Table 3 represents the results of non-parametric Phillips-Perron (P-P) for daily (Panel A), weekly (Panel B) and monthly (Panel C) index returns.

In Table, the findings of the P-P test support the results of ADF test that the data is stationary at the level for daily, weekly and monthly series as P-value (0.000) is significant at $1 \%$ level.

In nutshell, the results of ADF and P-P support stationarity hypothesis at level data at $5 \%$ significance. The results about both tests significantly reject the random behavior of stock prices for the KSE-100 Index series and show that the series follow 
Table 2: Results of ADF Test for the Level Series (1991-2015)

\begin{tabular}{|c|c|c|c|}
\hline \multicolumn{4}{|c|}{ Panel A: ADF Test for Daily Index Returns } \\
\hline \multicolumn{4}{|c|}{ Ho: Return has a unit root (Daily) } \\
\hline & & t-statistics & Prob.* \\
\hline \multicolumn{2}{|c|}{ Augmented Dickey-Fuller test statistic } & -48.56885 & 0.0001 \\
\hline \multirow{3}{*}{ Test critical values: } & $1 \%$ level & -3.431284 & \\
\hline & $5 \%$ level & -2.861838 & \\
\hline & $10 \%$ level & -2.566971 & \\
\hline \multicolumn{4}{|c|}{ Panel B: ADF Test for Weekly Index Returns } \\
\hline \multicolumn{4}{|c|}{ H0: Return has a unit root (Weekly) } \\
\hline & & t-statistics & Prob. $^{*}$ \\
\hline \multicolumn{2}{|l|}{ ADF Test statistics } & -29.37266 & 0.0000 \\
\hline \multirow[t]{3}{*}{ Critical Value } & $10 \%$ level & -2.567936 & \\
\hline & $5 \%$ level & -2.863637 & \\
\hline & $1 \%$ level & -3.435352 & \\
\hline \multicolumn{4}{|c|}{ Panel C: ADF Test for Monthly Index Returns } \\
\hline \multicolumn{4}{|c|}{ H0: Return has a Unit root (Monthly) } \\
\hline & & t-statistics & Prob.* \\
\hline \multicolumn{2}{|c|}{ Augmented Dickey-Fuller test statistic } & -16.59356 & 0.0000 \\
\hline \multirow[t]{3}{*}{ Test critical values: } & $1 \%$ level & -3.452911 & \\
\hline & $5 \%$ level & -2.871367 & \\
\hline & $10 \%$ level & -2.572078 & \\
\hline
\end{tabular}

* One-sided p-values by MacKinnon (1996)

a specific pattern and are not randomly distributed and give no direction for the WF-EMH.

\subsection{Autocorrelation Test}

The ACF and $\mathrm{PACF}^{6}$ for the time series returns of sample period is shown in Table 4 as the lag order is taken 23 (or degree of freedom is 23) due to sample years of 24.

6 Auto Correlation Function (ACF) refers that there is zero covariance and correlation among all changed disturbances. Autocorrelation mostly occurs in time series data. Partial Auto Correlation Function (PACF) refers a regression of the returns against its past lags. The PACF is basically the lagged correlations adjusted for the effect of lower order correlation (Gujarati EF Porter, 2008). 
Table 3: Result of Phillips-Perron (P-P) Test for the Level Series (1991-2015)

\begin{tabular}{|c|c|c|c|}
\hline \multicolumn{4}{|c|}{ Panel A: P-P test for Daily Index Returns } \\
\hline \multicolumn{4}{|c|}{ H0: Return has a unit root (Daily) } \\
\hline & & Adj.t-statistics & Prob.* \\
\hline \multicolumn{2}{|c|}{ Phillips-Perron test statistic } & -69.99831 & 0.0001 \\
\hline \multirow{3}{*}{ Test critical values: } & $10 \%$ level & -3.431284 & \\
\hline & $5 \%$ level & -2.861838 & \\
\hline & $1 \%$ level & -2.566971 & \\
\hline \multicolumn{4}{|c|}{ Panel A: P-P test for Weekly Index Returns } \\
\hline \multicolumn{4}{|c|}{ H0: Return has a unit root (Weekly) } \\
\hline & & Adj.t-statistics & Prob.* \\
\hline \multicolumn{2}{|l|}{ P-P Test statistic } & -29.63485 & 0.0000 \\
\hline \multirow[t]{3}{*}{ Critical Value } & $10 \%$ level & -2.567936 & \\
\hline & $5 \%$ level & -2.863637 & \\
\hline & $1 \%$ level & -3.435352 & \\
\hline \multicolumn{4}{|c|}{ Panel C: P-P test for Daily Index Returns } \\
\hline \multicolumn{4}{|c|}{ HO: Return has a unit root (Monthly) } \\
\hline & & Adj.t-statistics & Prob. ${ }^{*}$ \\
\hline \multicolumn{2}{|c|}{ P-P Test statistic } & -16.60680 & 0.0000 \\
\hline \multirow[t]{3}{*}{ Critical Value } & & -2.567936 & \\
\hline & & -2.863637 & \\
\hline & & -3.435352 & \\
\hline
\end{tabular}

* One-sided p-values by MacKinnon (1996)

For daily and weekly returns, the significant value of autocorrelations (Q-statistic) gives another proof regarding the rejection of random walk as the p-value is less than 0.05. The results are significant at very first lag for daily and weekly returns only (Haque et al., 2011; Tahir, 2011; Kiani, 2006 and Mobarek, 2000). These functions portray the pattern of sequential reliance in the time series returns. The Table 4 shows that the series is correlated at first order. The error happening in $(t)$ period can proceed to the next period $(t+1)$. The null hypothesis is rejected for no autocorrelation, this implies that successive values are correlated to one another and can be utilized for future predictions. Ultimately it is not a random series and does not qualify for weak form of efficiency on the basis of daily and weak bases.

However, monthly returns show different results as Q-stat are not significant at $5 \%$ significance of level. It refers that lag monthly returns are not correlated with 
current data and hence justify random behavior in series and supports weak form of efficiency. This result for monthly returns is not surprising for emerging market of Pakistan as the market does not have a long memory to correlate the current monthly prices with previous monthly prices.

\begin{tabular}{|c|c|c|c|c|c|c|c|c|c|c|c|c|c|c|c|c|c|c|c|c|c|c|c|}
\hline & $\begin{array}{c}0 \\
0 \\
2 \\
2\end{array}$ & $\begin{array}{l}\hat{\hat{b}} \\
\hat{0}\end{array}$ & & $\begin{array}{c}\tilde{0} \\
0\end{array}$ & & & & & $\begin{array}{l}0 \\
\vdots \\
0 \\
0\end{array}$ & $\begin{array}{l}+ \\
\infty \\
\\
0\end{array}$ & ふे & $\begin{array}{l}0 \\
+ \\
0 \\
0\end{array}$ & 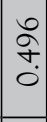 & $\begin{array}{l}\tilde{n} \\
\hat{n} \\
0\end{array}$ & & 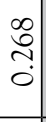 & & 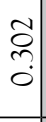 & $c$ & $\begin{array}{l}\widetilde{0} \\
0\end{array}$ & & & $\begin{array}{c}\text { I } \\
\text { Oे }\end{array}$ \\
\hline$\frac{7}{5}$ & $\mid \begin{array}{l}\pi \\
\tilde{a} \\
\dot{a}\end{array}$ & 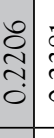 & 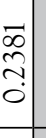 & & & & & $\begin{array}{l}7 \\
0 \\
0 \\
\vdots \\
0\end{array}$ & 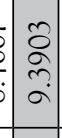 & $\mid \begin{array}{l}\overrightarrow{0} \\
\stackrel{0}{0} \\
\end{array}$ & $\begin{array}{l}\underset{J}{0} \\
= \\
=\end{array}$ & 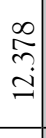 & $\begin{array}{l}\stackrel{ }{\beth} \\
=\end{array}$ & $\mid \begin{array}{l}\vec{f} \\
\vec{\beth} \\
\beth\end{array}$ & & $\begin{array}{l}\overline{0} \\
\vdots \\
\vdots \\
\end{array}$ & 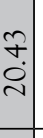 & 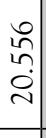 & 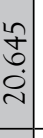 & \begin{tabular}{l}
9 \\
\multirow{2}{*}{} \\
$\dot{v}$
\end{tabular} & 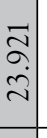 & & \\
\hline 8 & 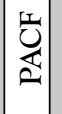 & $\begin{array}{l}\widetilde{1} \\
\vdots \\
0\end{array}$ & $\begin{array}{l}\infty \\
⿱ \\
\vdots \\
\vdots \\
\vdots\end{array}$ & & & & & $\stackrel{\infty}{c}$ & 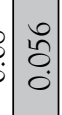 & $\begin{array}{l}\bar{\delta} \\
\dot{\rho} \\
\dot{0}\end{array}$ & $\begin{array}{l}\stackrel{2}{0} \\
\stackrel{0}{0}\end{array}$ & $\begin{array}{l}\tilde{o} \\
\hat{Q} \\
\dot{Q}\end{array}$ & $\mid \begin{array}{l}\overline{0} \\
\dot{0} \\
\end{array}$ & $\mid \begin{array}{l}0 \\
0 \\
0 \\
1\end{array}$ & $\stackrel{\widetilde{n}}{\stackrel{0}{9}}$ & $\begin{array}{l}\widetilde{0} \\
0 \\
0\end{array}$ & $c$ & $\begin{array}{l}\tilde{y} \\
\tilde{0} \\
\vdots \\
\vdots\end{array}$ & & $\begin{array}{l}0 \\
0 \\
0 \\
0\end{array}$ & & & \\
\hline & 萦 & $\begin{array}{l}\widetilde{a} \\
\vdots \\
0\end{array}$ & & $\begin{array}{l}n \\
\hat{o} \\
\dot{Q}\end{array}$ & & & $\begin{array}{c}c \\
c \\
\end{array}$ & ț & $\begin{array}{l}n \\
\vdots \\
\vdots \\
0 \\
0\end{array}$ & $\begin{array}{l}n \\
0 \\
0 \\
0\end{array}$ & $\begin{array}{l}0 \\
0 \\
0 \\
0 \\
0\end{array}$ & $\begin{array}{l}n \\
0 \\
0 \\
i\end{array}$ & $\begin{array}{l}8 \\
8 \\
0\end{array}$ & $\left|\begin{array}{l}0 \\
\text { ठे } \\
\dot{i}\end{array}\right|$ & \begin{tabular}{l}
0 \\
\multirow{1}{*}{} \\
0
\end{tabular} & $\begin{array}{l}\text { ज्ञ } \\
\text { : }\end{array}$ & ¿ & $\begin{array}{l}\tilde{0} \\
\dot{Q}\end{array}$ & c & 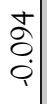 & 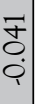 & $\begin{array}{l}\text { ğ } \\
g \\
c\end{array}$ & 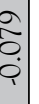 \\
\hline & $\mid \begin{array}{l}0 \\
0 \\
2 \\
2\end{array}$ & $\begin{array}{l}8 \\
\vdots \\
\vdots\end{array}$ & & & & & & 8 & & 8 & 8 & $\begin{array}{l}8 \\
0\end{array}$ & $\begin{array}{l}8 \\
0\end{array}$ & $\begin{array}{l}8 \\
0\end{array}$ & & $\begin{array}{l}8 \\
0\end{array}$ & 8 & $\begin{array}{l}8 \\
0\end{array}$ & 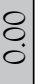 & 8 & 8 & $\begin{array}{l}8 \\
0 \\
0\end{array}$ & 8 \\
\hline$\frac{7}{2}$ & $\begin{array}{l}\tilde{\pi} \\
\vec{\omega} \\
\dot{\alpha}\end{array}$ & 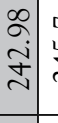 & 芦. & $\stackrel{r}{\stackrel{\sim}{\sim}}$ & 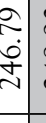 & 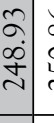 & 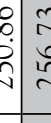 & $\begin{array}{l}5 \\
\text { in } \\
7\end{array}$ & $\hat{\sim}$ & \begin{tabular}{|l}
$n$ \\
0 \\
0 \\
$i$ \\
\end{tabular} & $\begin{array}{l}\text { ㅈ } \\
\text { İ } \\
\text { N }\end{array}$ & $\begin{array}{l} \pm \\
\vdots \\
\dot{U} \\
\text {. }\end{array}$ & $\begin{array}{l}\hat{b} \\
\vec{j} \\
i \\
\end{array}$ & $\begin{array}{l}\tilde{\hat{d}} \\
\dot{\sim}\end{array}$ & 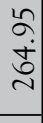 & 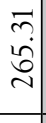 & $\mathfrak{z}$ & 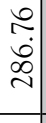 & ठ઼. & $\begin{array}{l}\text { ln } \\
\vdots \\
\vdots \\
\vdots\end{array}$ & ઢे & 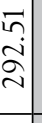 & \begin{tabular}{l}
$\infty$ \\
\multirow{2}{2}{} \\
\multirow{2}{2}{}
\end{tabular} \\
\hline & 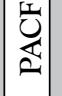 & $\begin{array}{l}\text { 이 } \\
+ \\
0\end{array}$ & 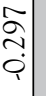 & & בे & $\begin{array}{c}\vec{m} \\
\overrightarrow{0}\end{array}$ & 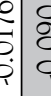 & $\mid \begin{array}{l}\infty \\
0 \\
0\end{array}$ & $\begin{array}{l}2 \\
\dot{Q} \\
\dot{Q}\end{array}$ & $\begin{array}{l}\tilde{\delta} \\
\dot{Q} \\
\dot{0}\end{array}$ & : & $\mid \begin{array}{l}8 \\
0 \\
0 \\
0\end{array}$ & $\begin{array}{l}\mathcal{J} \\
0 \\
0\end{array}$ & $\mid \begin{array}{l}\overrightarrow{0} \\
\stackrel{0}{0}\end{array}$ & $\begin{array}{l}\circ \\
\text { oे } \\
\stackrel{0}{0}\end{array}$ & $\begin{array}{l}a \\
0 \\
\dot{0} \\
\dot{p}\end{array}$ & $\begin{array}{l}\dot{y} \\
0 \\
0 \\
0\end{array}$ & $\begin{array}{l}\text { ô } \\
\text { Qे }\end{array}$ & นี & $\begin{array}{l}0 \\
0 \\
0 \\
\vdots\end{array}$ & $\begin{array}{l}\text { Oे } \\
\text { Q }\end{array}$ & 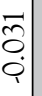 & $\infty$ \\
\hline & $\left|\begin{array}{l}\mid r \\
\\
\end{array}\right|$ & 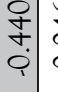 & $\begin{array}{l}0 \\
0 \\
0 \\
\vdots \\
\vdots\end{array}$ & & ठे & & 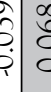 & $\tilde{a}$ & & fै & $\mid \begin{array}{l}1 \\
f \\
0 \\
\dot{q}\end{array}$ & $\begin{array}{l}\overrightarrow{0} \\
\dot{0} \\
\dot{0}\end{array}$ & \begin{tabular}{|}
\multirow{J}{J}{} \\
0 \\
0
\end{tabular} & \begin{tabular}{|c}
$\tilde{\sigma}$ \\
$\delta$ \\
$\dot{Q}$
\end{tabular} & $\begin{array}{l}\overline{\hat{O}} \\
\dot{\varphi}\end{array}$ & $\begin{array}{l}\widetilde{0} \\
0 \\
0\end{array}$ & $\begin{array}{l}\tilde{0} \\
0 \\
0\end{array}$ & $\begin{array}{l}-\tilde{0} \\
0 \\
0 \\
0\end{array}$ & पू & $\begin{array}{l}\overrightarrow{3} \\
\dot{Q} \\
\end{array}$ & 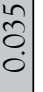 & ç & $\tilde{c}$ \\
\hline & 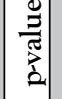 & $\begin{array}{l}8 \\
\circ \\
\circ\end{array}$ & \begin{tabular}{l}
8 \\
\hdashline \\
\end{tabular} & $\begin{array}{l}8 \\
0 \\
0\end{array}$ & $\begin{array}{c}8 \\
\\
\end{array}$ & \begin{tabular}{l|l}
8 \\
$\circ$ \\
\end{tabular} & s. & 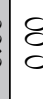 & $\mid \begin{array}{l}8 \\
0 \\
0\end{array}$ & ৪ & 8 & 8 & $\begin{array}{l}8 \\
0 \\
\end{array}$ & $\begin{array}{l}8 \\
0 \\
0\end{array}$ & & $\begin{array}{l}8 \\
0 \\
0\end{array}$ & 8 & $\begin{array}{l}8 \\
0 \\
0\end{array}$ & 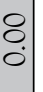 & 8 & C & $\begin{array}{l}8 \\
0 \\
0\end{array}$ & 8 \\
\hline & $\mid \begin{array}{c}\dot{\vec{\sharp}} \\
\dot{\hat{d}}\end{array}$ & 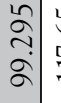 & | & 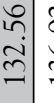 & 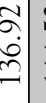 & 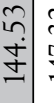 & $\begin{array}{l}4 \\
3 \\
4\end{array}$ & $\begin{array}{l}\infty \\
0 \\
0 \\
0\end{array}$ & 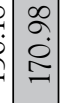 & $\stackrel{\widetilde{\infty}}{\stackrel{\sim}{\Xi}}$ & 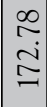 & 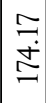 & $\begin{array}{l}\infty \\
\infty \\
\vdots \\
\\
\end{array}$ & 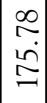 & & 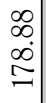 & $\begin{array}{c}\vec{s} \\
\vdots \\
0 \\
0\end{array}$ & $\begin{array}{l}\mathbb{N} \\
\stackrel{0}{0} \\
\vdots\end{array}$ & $\stackrel{7}{\beth}$ & 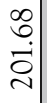 & छे & 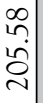 & I \\
\hline & 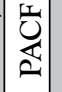 & & 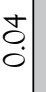 & $\begin{array}{c}\hat{\tilde{o}} \\
\hat{0}\end{array}$ & $\begin{array}{c} \pm \\
0 \\
0 \\
0\end{array}$ & $\begin{array}{c}0 \\
\text { D. } \\
\text {. }\end{array}$ & $\vec{s}$ & $\begin{array}{l}\stackrel{J}{\Xi} \\
\stackrel{0}{0}\end{array}$ & \begin{tabular}{|l|l} 
\\
0 \\
0 \\
0
\end{tabular} & 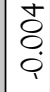 & $\mid \begin{array}{l} \\
\text { ठ } \\
0 \\
\end{array}$ & \begin{tabular}{|l}
$\infty$ \\
0 \\
0 \\
0
\end{tabular} & $\begin{array}{l}\text { t) } \\
\text { ठ } \\
\end{array}$ & $\mid \begin{array}{l}0 \\
\vdots \\
0 \\
\end{array}$ & & $\begin{array}{l}\approx \\
\Xi \\
0 \\
0\end{array}$ & $\tilde{\check{c}}$ & 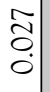 & c & 0 & ¿ & $\begin{array}{l}\overrightarrow{0} \\
\stackrel{0}{\circ} \\
\stackrel{0}{0}\end{array}$ & \\
\hline & 堅 & $\stackrel{7}{\circ}$ & 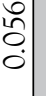 & ?o & $\begin{array}{c}\tilde{c} \\
0 \\
0 \\
0\end{array}$ & 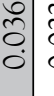 & 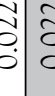 & $\begin{array}{l}\tilde{0} \\
0 \\
0\end{array}$ & $\begin{array}{l}2 \\
0 \\
0 \\
0\end{array}$ & Iี & Iี & $\begin{array}{l}2 \\
0 \\
0 \\
0\end{array}$ & $\begin{array}{l}\overrightarrow{0} \\
0 \\
0\end{array}$ & $\begin{array}{l}n \\
0 \\
0 \\
0\end{array}$ & & $\begin{array}{l}0 \\
0 \\
0 \\
0\end{array}$ & 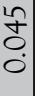 & $\begin{array}{l}\vec{f} \\
\stackrel{0}{0} \\
0\end{array}$ & 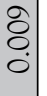 & $\begin{array}{l}\grave{0} \\
\grave{0}\end{array}$ & & $\begin{array}{l}\widetilde{0} \\
\dot{0} \\
\end{array}$ & $\bar{z}$ \\
\hline & & & & & + & & & D & & 으 & $=$ & $\simeq$ & $\approx$ & \pm & & 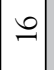 & $=$ & $\stackrel{\infty}{-1}$ & & ㄱ & & & \\
\hline
\end{tabular}




\subsection{Results of Runs Test}

The non-parametric run test has no concern with non-normality of descriptive statistics. For the hypothesis of randomness, the positive numbers of runs are independent of negative runs and vice versa. The test assumes that runs do not follow any systematic pattern of occurrence which refers that there is no predictable pattern of run occurrence. Null hypothesis is rejected at $5 \%$ level of significance. Whenever Z-value is larger than \pm 1.96 (Sharma \& Kennedy, 1977), it refers that the data is random or mutually independent. Table 5 shows the results of run test for daily, weekly and monthly index returns. As per findings, the value from claiming "Z-statistic" is negative; these negative values for Z-Statistic demonstrates that the real number of runs are less than expected number. The Z-value for daily (-3.66672) and weekly (-2.17122) is more than critical value at $5 \%$ level of significance which refers that there is no randomness in the returns and hence nullifies the weak form of efficiency (Mobarek, 2000 and Poshakwale, 1996). However, the z-value of monthly returns $(-0.30293)$ is less than its critical value (-1.96) which supports randomness in the data and supports weak form of efficiency (Sheikh \& Noreen, 2012). The outcomes about run test are similar and comparative with results.

Table 5: Runs Test for the KSE-100 Index for the Sample Period 1991-2015

\begin{tabular}{|c|c|c|c|}
\hline \multicolumn{4}{|c}{ Runs Test Sample 11/2/1991 to 12/31/2015 } \\
\hline & $\begin{array}{c}\text { Daily Index } \\
\text { Return }\end{array}$ & $\begin{array}{c}\text { Weekly Index } \\
\text { Return }\end{array}$ & $\begin{array}{c}\text { Monthly Index } \\
\text { Return }\end{array}$ \\
\hline $\mathrm{R}=$ Actual Runs & 2538 & 517 & 137 \\
\hline $\mathrm{No}=$ Negative Runs & 2874 & 586 & 131 \\
\hline $\mathrm{N} 1=$ Positive Runs & 2997 & 669 & 158 \\
\hline $\mathrm{N}=$ Total Observations & 5871 & 1255 & 289 \\
\hline $\mathrm{E}(\mathrm{R})=$ Expected Runs & 2935.21 & 625.75 & 144.23 \\
\hline $\mathrm{Var}(\mathrm{R})=$ Variance & 11735.15 & 2508.95 & 571.01 \\
\hline StDev (R)= Standard Deviation & 108.32 & 50.08 & 23.89 \\
\hline $\mathrm{Z}=$ & -3.66 & -2.17 & -0.302 \\
\hline $\mathrm{P}$-Value = 2-sided & 0.00024 & 0.029 & 0.761 \\
\hline & Non-Random & Non-Random & Random \\
\hline
\end{tabular}

\section{Conclusion}

This study analyses the weak form of efficient market hypothesis on the basis that returns follow random walk hypothesis. For the reason, the paper analyses KSE-100 index of Pakistan Stock Exchange (formerly Karachi Stock Exchange) over a longer 
24 years (1991-2015) for 5871 daily; 1255 weekly and 289 monthly observations of the KSE-100 index. The descriptive statistics results illustrate that the distribution is non-normal, skewed negatively and leptokurtic for daily, weekly and monthly data. The findings of ADF and P-P tests rejects the assumption of non-stationarity at level data as the results indicate that these series are stationary and are significant at 5\% level unit root; it give some indication that returns series do not follow random walk. The study also tested the autocorrelation for return series by applying Lung-Box Q-Statistic for lag order 23. The results show significant Q-statistics for daily and weekly data only but insignificant for monthly data. The results for daily and weekly data reject the zero autocorrelation and prove that index returns are predictable and KSE is not an efficient in weak form. Ultimately run test of randomness reject random walk for daily and weekly returns but find existence of randomness for monthly data.

In view of those outcomes of the different tests, this study demonstrates that Pakistani market does not follow random walk and nullify weak form of efficiency for daily and weekly data. Based on the assumption of weak form of efficiency, it may refer that investors can make abnormal returns on basis of historical share prices (Malhotra et al., 2015).

The issue of testing market efficiency is important to security analysts, investors for investment decision, and stock market regulators for governing financial market regarding flow of information in the market. The availability of all "free of cost" information to the investors and the usage of more sophisticated system for the floatation of information will make it difficult for the investors to beat the market with past prices information and make abnormal returns. The EMH demands continuous research efforts in order to acquire more comprehensive conclusion with the help of more sophisticated models.

\section{References}

Abeyratna, G., \& Power, D. M. (1995). A test of the weak-form of the efficient market hypothesis: Evidence using daily data from the Colombo Stock Exchange. Sri Lanka Journal of Social Sciences, $18(1 \& 2), 41-53$.

Aga, M., \& Kocaman, B. (2008). Efficient Market Hypothesis and Emerging Capital Markets: Empirical Evidence from Istanbul Stock Exchange. International Research Journal of Finance and Economics, 13(1), 131-144.

Ahmad, K. M., Ashraf, S., \& Ahmed, S. (2006). Testing Weak Form Efficiency for India Stock Markets. Economic and Political Weekly, 7, 49-56.

Akhtar, S., \& Khan, N. U. (2016). Modeling volatility on the Karachi Stock Exchange, Pakistan. Journal of Asian Business Studies, 10(3), 253-275. 
Azad, A. S. M. (2009). Efficiency, co-integration and contagion in equity markets: Evidence from China, Japan and South Korea. Asian Economic Journal, 23(1), 93-118.

Bley, J. (2011). Are GCC stock markets predictable? Emerging Markets Review, 12(3), 217-237.

Butler, K. C., \& Malaikah, S. J. (1992). Efficiency and inefficiency in thinly traded stock markets: Kuwait and Saudi Arabia. Journal of Banking $\mathcal{E}$ Finance, 16(1), 197-210.

Chong, T. T. L., Lam, T. H., \& Yan, I. K. M. (2012). Is the Chinese stock market really inefficient? China Economic Review, 23(1), 122-137.

Chiat, H. S., \& Finn, F. J. (1983). Random walks on the stock exchange of Singapore. Accounting $\mathcal{E}$ Finance, 23(2), 81-87.

Cooper, J. C. (1982). World stock markets: Some random walk tests. Applied Economics, 14(5), 515-531.

Ekechi, A. O. (1989). Weak-form efficiency in the Nigerian Stock Exchange. African Review of Money Finance and Banking, 1, 5-16.

Fama, E. F. (1970). Efficient capital markets: A review of theory and empirical work. The Journal of Finance, 25(2), 383-417.

Gujarati, D. N., \& Porter, D. C. (2008). Basic econometrics (5 ${ }^{\text {th }}$ ed.). New Delhi: Student Book Company.

Groenewold, N., Tang, S. H. K., \& Yanrui, W. U. (2004). The dynamic interrelationships between the greater China share markets. China Economic Review, 15(1), 45-62.

Haider, S., \& Nishat, M. (2009). On testing efficiency of Karachi Stock Exchange using computational intelligence. In proceedings of the 2009 International Conference on Information and Financial Engineering (ICIFE) (pp. 32-36).

Haque, A., Liu, H. C., \& Nisa. F. U. (2011). Testing the week form efficiency of Pakistan stock market (2000-2010). International Journal of Economics and Financial Issues, 1(4), 153-162.

Hasan, M. Z., Kamil, A. A., Mustafa, A., \& Baten, M. A. (2012). Stochastic frontier model approach for measuring stock market efficiency with different distributions. PloS one, 7(5), e37047.

Jethwani, K., \& Achuthan, S. (2013). Stock market efficiency and crisis: Evidence from India. Asia-Pacific Finance and Accounting Review, 1(2), 35.

Kiani, K. M. (2006). Predictability in stock returns in an emerging market: Evidence from KSE 100 stock price index. The Pakistan Development Review, 45(3), 369-381.

Kim, J. H., Shamsuddin, A., \& Lim, K. P. (2011). Stock return predictability and the adaptive markets hypothesis: Evidence from century-long US data. Journal of Empirical Finance, 18(5), 868-879.

Laopodis, N. T. (2004). Financial market liberalization and stock market efficiency: Evidence from the Athens Stock Exchange. Global Finance Journal, 15(2), 103-123. 
MacKenzie, D. (2006). An engine not a camera: How financial model shape markets. Cambridge: The MIT Press.

Malhotra, N., Tandon, K., \& Tandon, D. (2015). Testing the empirics of weak form of efficient market hypothesis: Evidence from Asia-Pacific markets. IUP Journal of Applied Finance, 21(4), 18-37.

Mishra, P. K. (2011). Weak form market efficiency: Evidence from emerging and developed world. The Journal of Commerce, 3(2), 26.

Mobarek, A. (2000). Weak-form market efficiency of an emerging market: Evidence from Dhaka stock market of Bangladesh. Paper presented at the ENBS Conference held on Oslo, May, 2000.

Mustafa, K., \& Nishat, M. (2007). Testing for market efficiency in emerging markets: A case study of the Karachi Stock Market. The Journal of Economics, 12(1), 119-140.

Mukhopadhyay, D., \& Sarkar, N, (2005). Testing predictability and nonlinear dependence in the Indian stock market. Emerging Markets Finance and Trade, 41(6), 7-44.

Mollah, A. S. (2007). Testing weak-form market efficiency in emerging market: Evidence from Botswana Stock Exchange. International Journal of Theoretical and Applied Finance, 10(06), 1077-1094.

Opong, K. K., Mulholland, G., Fox, A. F., \& Farahmand, K. (1999). The behavior of some UK equity indices: An application of Hurst and BDS tests. Journal of Empirical Finance, 6(3), 267-282.

Pele, D. T., \& Voineagu, V. (2008). Testing market efficiency via decomposition of stock return: Application to Romanian capital market. Romanian Journal of Economic Forecasting, 3, 63-79.

Phillips, P. C., \& Perron, P. (1988). Testing for a unit root in time series regression. Biometrika, 75(2), 335-346.

Poshakwale, S. (2002). The random walk hypothesis in the emerging Indian stock market. Journal of Business Finance $\mathcal{E}$ Accounting, 29(9-10), 1275-1299.

Poshakwale, S. (1996). Evidence on weak form efficiency and day of the week effect in the Indian stock market. Finance India, 10(3), 605-616.

Rehman, S., \& Qamar, M. R. (2014). Testing Weak form efficiency of capital market: A case of Pakistan. International Journal of Research Studies in Management, 3(1), 65-73.

Said, A., \& Harper, A. (2015). The efficiency of the Russian stock market: A revisit of the random walk hypothesis. Academy of Accounting and Finance Studies Journal, 19(1), 42-48.

Sharma, J. L., \& Kennedy, R. E. (1977). A comparative analysis of stock price behavior on the Bombay, London, and New York stock exchanges. Journal of Finance and Quantitative Analysis, 12(03), 391-413.

Seiler, M. J., \& Rom. W. (1997). A historical analysis of market efficiency: Do historical returns follow a random walk? Journal of Finance and Strategic Decisions, 10(2), 49-57.

Sheikh, M. J., \& Noreen. U. (2012). Validity of efficient market hypothesis: Evidence from UK mutual funds. African Journal of Business Management, 6(2), 514-520. 
Su, J. J., Roca, E., \& Wong, V. S. H. (2015). The efficiency of Asian stock markets: Fresh evidence based on new tests. Discussion Paper, Griffith Business School

Sultan, K., Madah, N. A., \& Khalid, A. (2013). Comparison between Kuwait and Pakistan Stock exchange market: Testing weak form of efficient market. Academy of Contemporary Research Journal, 7(2), 59-70.

Tahir, A. (2011). Capital market efficiency: Evidence from Pakistan. Interdisciplinary Journal of Contemporary Research in Business, 3(8), 947-953.

Wright, J. H. (2000). Alternative variance-ratio tests using ranks and signs. Journal of Business $\mathcal{E}$ Economic Statistics, 18(1), 1-9.

Wong, K. A., \& Kwong, K. S. (1984). The behavior of Hong Kong stock prices. Applied Economics, 16(6), 905-917.

Yalawar, Y. B. (1988). Bombay Stock Exchange: Rates of return and efficiency. Indian Economic Journal, 35(4), 68-121. 


\section{Appendices}

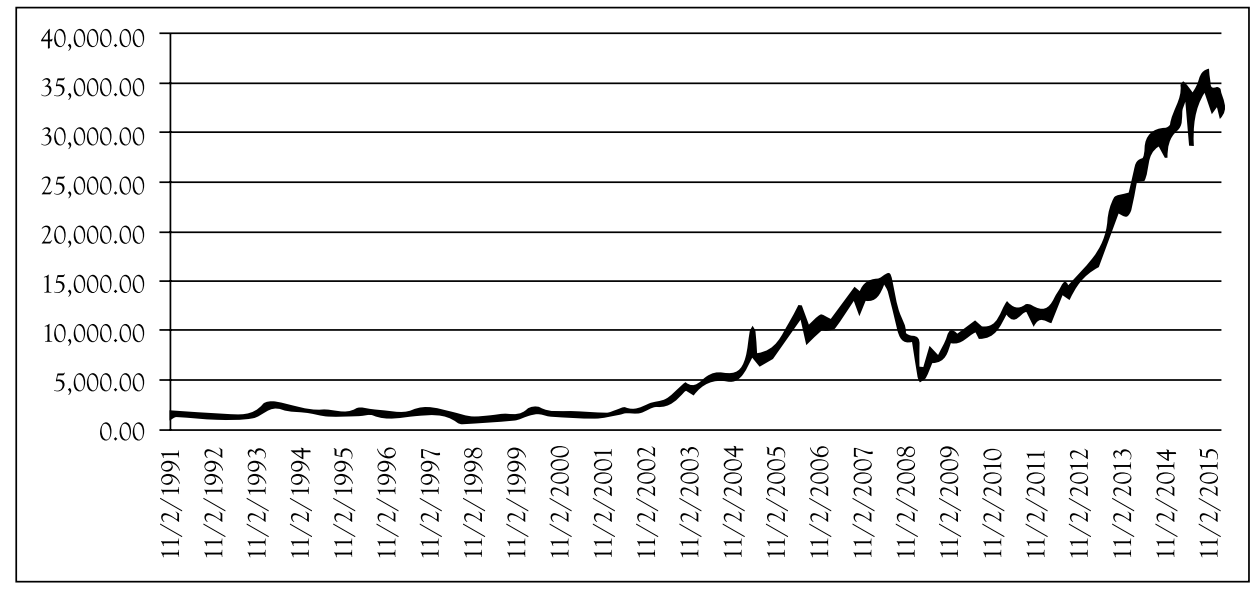

Figure 1: Closing Index Prices (November 1991- December 2015)

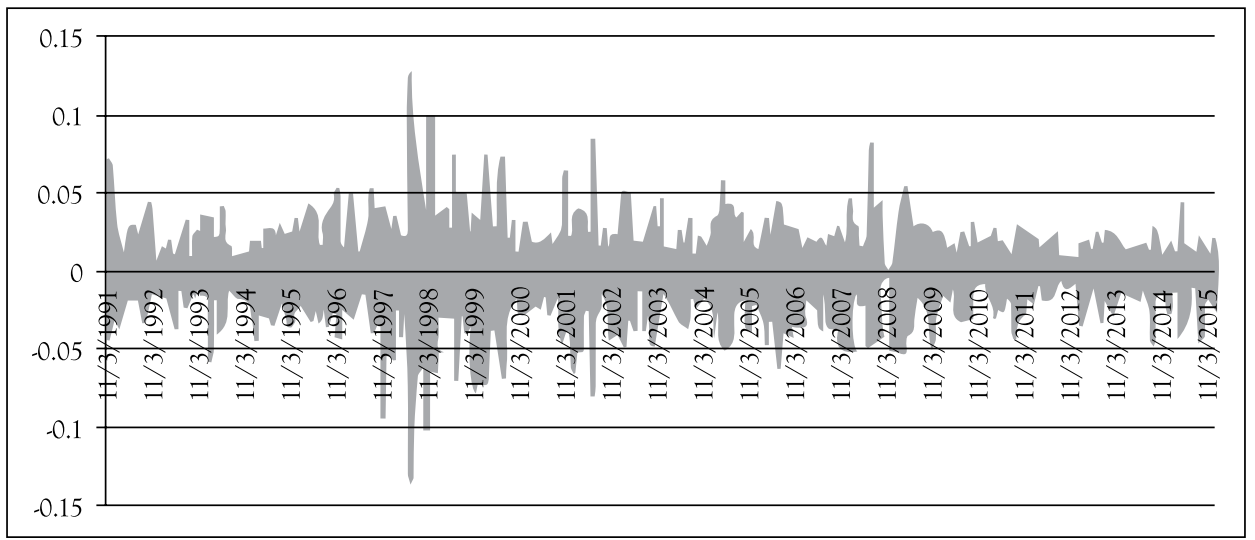

Figure 2: Index Returns (November 1991- December 2015) 